\title{
KOMÁRNO IN THE LA TÈNE PERIOD ${ }^{1}$
}

\author{
GERTRÚDA B ŘEZINOVÁ — - M A R E K G E R E
}

\begin{abstract}
In this exceptional strategical location on the confluence of the Danube and Váh river we have evidence of settlement in the end of the Middle and Late La Tène period. Although no area excavation has been carried out yet, important finds and features supported by rescue excavations allow us to classify this locality as an important site. Features and finds have been confirmed at eight locations. As for settlement features, they are pits of various functions and production features including the remarkable site of Nádvorie Európy square with a series of six pottery kilns. They produced high-quality goods made on potter's wheel which also contained painted pottery. We suppose that Komárno in the La Tène period was one of eminent locations with concentration of production and trade. Thus, contacts were directed to the north, along the so-called Váh route, as well as southwards and southwestwards.
\end{abstract}

Keywords: Southwestern Slovakia, Late La Tène Period, settlement agglomeration, settlement of central status, production features, pottery, coins.

\section{INTRODUCTION}

The town of Komárno is located in the exceptional transportation-geographical location directly controlling the Dunaj (Danube) and Váh's streams. As it has been showing recently, it was the territory of these two rivers' confluence where the most intense settlement documented in the Neolithic and Eneolithic, La Tène and Roman periods as well as in the Middle Ages and Postmedieval period was situated. The choice of the site for settlement was not an accidental process in the La Tène period or any other historical period. It was a combination of factors which bearers of the La Tène culture took into consideration. The most important ones included proximity of water streams, favourable soil and climatic conditions, proximity of trade routes as well as sources of raw materials. The current Komárno's location met almost all the described attributes.

\section{THE GEOGRAPHICAL AND GEOLOGICAL SITUATION}

Komárno is the southernmost and the lowest located town in the territory of the Slovak Republic, near the confluence of the Váh and Danube rivers. From the aspect of geomorphology, the territory in question belongs to the central part of the Podunajská nížina (Danube lowland). The area here is a typical lowland. Hydrographically, it is part of the Danube river basin. Geographically, it belongs to the southern part of the Pannonian Basin, where it is part of the Gabčíkovská panva basin regional-geological unit (Miklós/Hrnčiarová 2002). Sediments of Tertiary and Quaternary can be found in the geological composition of the territory. The quaternary sediments in the studied area are represented mainly by fluvial facies of Holocenic sediments. These sediments' facial-genetic composition is diverse. Mostly, sandy flooded soils or quaternary clays are predominant. So-called buried riverbeds of older streams are frequently found in the neigbouring areas. Lithologically, they are made up of highly plastic clays, loams, less frequently very fine-grained grey to grey-black sands with a high proportion of organic substances. Their bedrock is built of fluvial sediments of lake-river origin, such as - mainly - sands and gravel sands with various proportions of sand with multi-stage polycyclic development which are collectors of quaternary groundwater. Hydrological conditions are directly associated with the geological structure. Fluvial sediments - gravels and sands flooded by the Danube and Váh rivers - are the principal bearers of groundwater. From the aspect of the total structure, the site is located in a zone where groundwaters come to the surface. In the narrow riparian zone, water levels of the Danube and Váh, less frequently precipitations and vapour, participate in the groundwater regime (Varjú 2009).

\footnotetext{
1 This work was supported by the Slovak Research and Development Agency under the Contract no. APVV-15-0491 and by VEGA project no. $1 / 240 / 21$.
} 


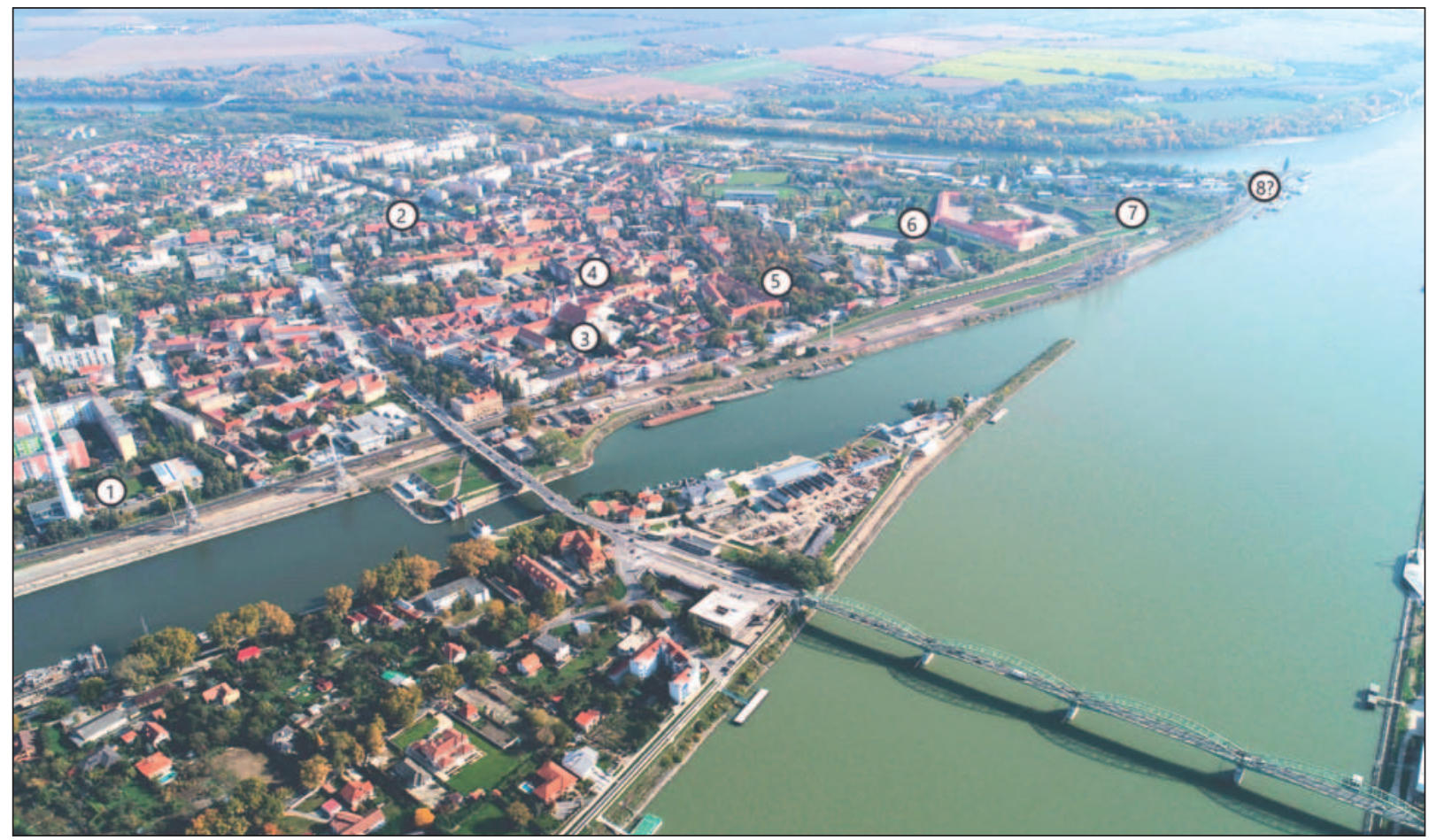

Fig. 1. Komárno, aerial photo. Location of La Tène sites. 1 - Dunajské nábrežie street; 2 - Kossuthovo námestie square; 3 - Palatínova ulica street; 4 - Nádvorie Európy square; 5 - Anglia Park; 6 - New Fortress; 7 - Old Fortress; 8? - location of the hoard of coins according to the catalogue of Saint Germain museum. Photo source: Komárno City Archive.

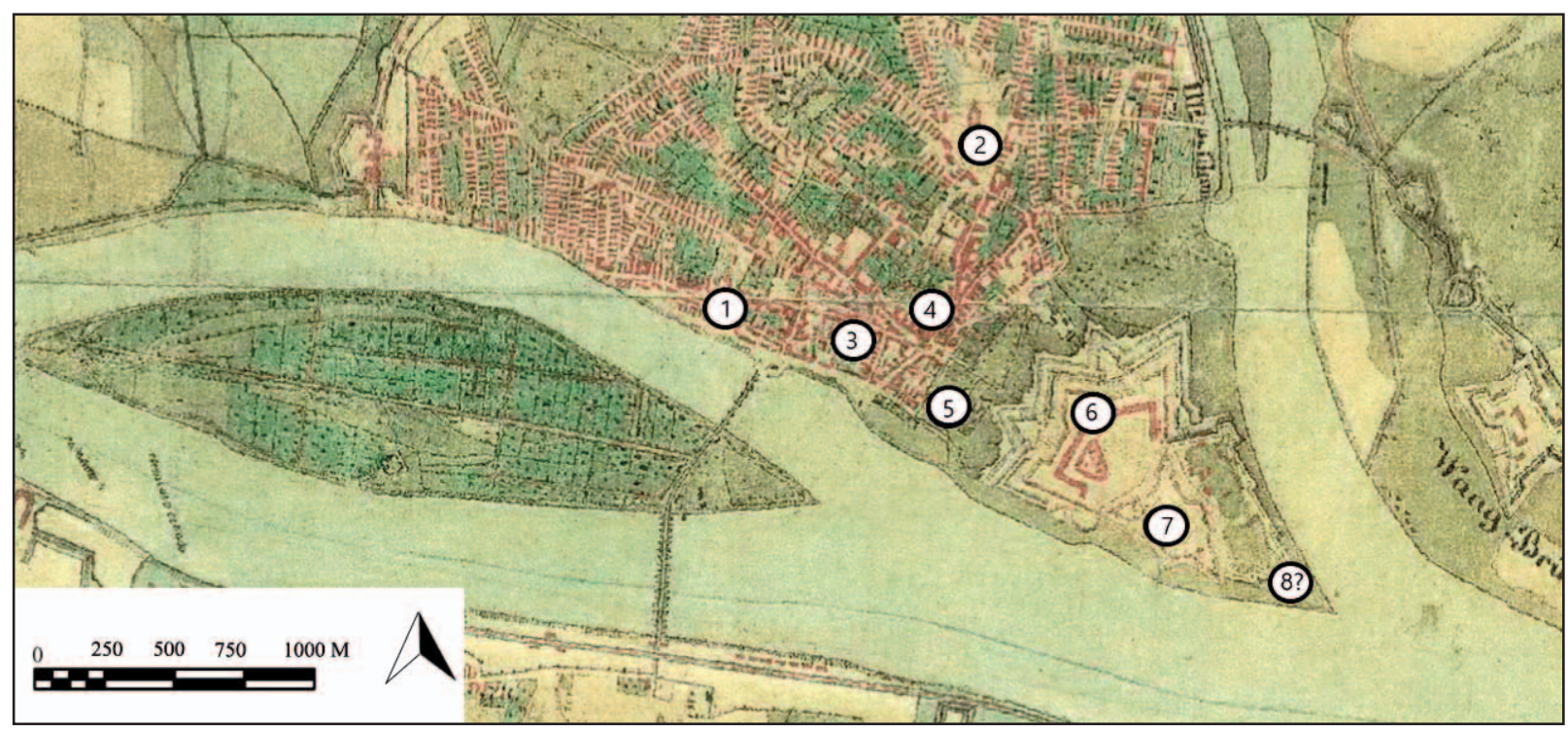

Fig. 2. Komárno, Second military survey. Location of La Tène sites. 1 - Dunajské nábrežie street; 2 - Kossuthovo námestie square; 3 - Palatínova ulica street; 4 - Nádvorie Európy square; 5 - Anglia Park; 6 - New Fortress; 7 - Old Fortress; 8? location of the hoard of coins according to the catalogue of Saint Germain museum. Map source: www.geoportal.gov.sk 


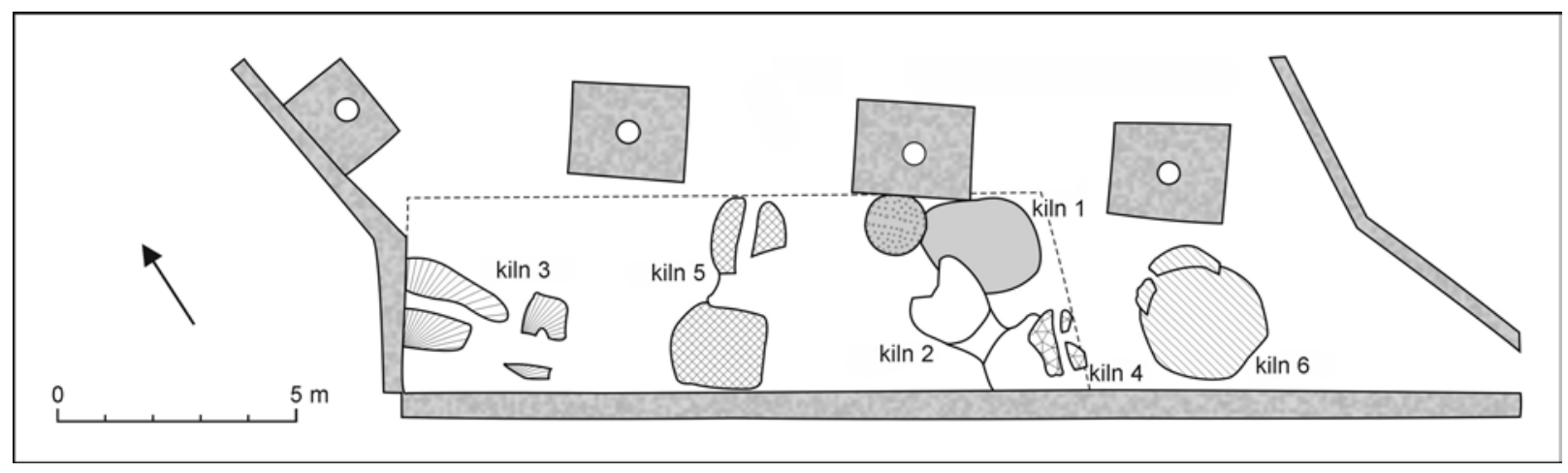

Fig. 3. Komárno, Nádvorie Európy square site. Spatial distribution of pottery kilns (based on materials from J. Koštial 2004 and K. Pieta 2008, adapted by M. Gere).

\section{RECORD OF INDIVIDUAL SITES WITH EVIDENCE OF LA TÈNE SETTLEMENT IN THE TOWN' CADASTRAL AREA}

(Fig. $1 ; 2)^{2}$

\section{Komárno, Dunajské nábrežie site.}

In 1978, an archaeological excavation was carried out in the area of Dunajské nábrežie street, where P. Ratimorská studied a circular pit dated to the La Tène period (Ratimorská 1980). Daub and fragments of pottery including part of a storage vessel with a massive rim.

2. Komárno, Kossuthovo námestie site - postmedieval cemetery from the $16^{\text {th }}-18^{\text {th }} \mathrm{c}$.

In 2011, during the rescue researsch of SAHI, o.z., a shallow feature with finds from the late La Tène period was uncovered. It is a settlement pit whose exact outline has not been detected. Its documented depth was $10-15 \mathrm{~cm}$. Several vessel fragments, one complete cup with a handle, daub and a dog skeleton come from its fill (Jelinek/ Teslíková/Gere 2011). The feature is dated to LTD.

3. Komárno, Palatínova ulica street site - church and postmedieval cemetery from the $16^{\text {th }}-18^{\text {th }} \mathrm{c}$.

In 1999, excavations led by P. Ratimorská and E. Dénešová were carried out at the courtyard of the service part of the Jesuit monastery in Komárno. It uncovered a fragment of postmedieval architecture. In addition, graves of the cemetery belonging to the St. Andrew's Church were found in all trenches. Mainly La Tène pottery was obtained from the studied areas, however, with regard to intense burying, it was only found in secondary position. Nevertheless, its quantitative representation suggest intense settlement of the site in the La Tène period. The archaeological and architectural research of the monastery building's norhtern wing in 2004 came to similar conclusions (Bednár 2006, 34; Bednár/Kvasnicovál Ratimorská 2005, 151).

4. Komárno, Nádvorie Európy (Courtyard of Europe) site. Research led by P. Ratimorská and K. Pieta studied the battery of 6 pottery kilns (Koštial 2004; Mangel/Thér
2018; Pieta 2008, 177, fig. 86: 1-11). The excavated area in 2000-2001 was approx. $130 \mathrm{~m}^{2}$, during 2003, after interior walls enclosing the current space had been built, it was $62 \mathrm{~m}^{2}$. The site is situated on a slight loess elevation under the tiled surface of today's square, on the premises of Europália shopping centre in the centre of Komárno. The basic terrain elevation is $108.75 \mathrm{~m}$ a.s.l. This value is a result of terrain works associated with construction of the shopping centre and is not the original terrain level of the site. The excavated area is approx. $4 \mathrm{~m}$ below the current surface of the courtyard. Another research was carried out there in 2020 by J. Koštial. It was focused on documentation of the remaining find situation (Fig. 3).

5. Komárno, Park Anglia site (previously known as Leninove sady and Mestský park).

A rescue research was carried out there in 1982. Three features with numerous sherds, iron slag and graphite from the La Tène period appeared in profiles of furrows (Ratimorská 1983, 211, 212). Besides sherds (Pieta 2008, fig. 77: 1-13; 86:1-11) representing storage vessels with massive rims, pots, bowls with everted rims, a situla with incompact horizontal combing, subtle bottle shapes and a bowl with a wavy line on its inner surface, fragments of painted vessels and a bronze brooch of the Beltz type were discovered there (Pieta 2008, fig. 77: 14).

6. Komárno, Nová pevnost' (New Fortress) site.

Two rescue excavations were carried out there. In 2012, the Archaeoservices s.r.o. company in cooperation with the Podunajské múzeum in Komárno carried out a rescue excavation. Five features and a cultural layer from the La Tène period were detected. Based on the evaluation of pottery, they can be dated to stages LTC2-LTD1 with extension probably to stage LTD2 (Gere 2013). Feature no. 6 was uncovered in furrow no. 7. It contained a large amount of iron slag (up to $10 \mathrm{~kg}$ ), sherds, daub and individual animal bones (Fig. 4).

The excavation at the site of New Fortress continued in 2019 as part of the project called 'New construction of a staircase down to the basement of Barracks from exterior' (Gere/Gereová 2019). A cultural layer (111.5-110.4 m

\footnotetext{
2 The authors of the article wish to thank PhDr. P. Ratimorská for her enormous effort to save archaeological monuments in the town and its surroundings.
} 

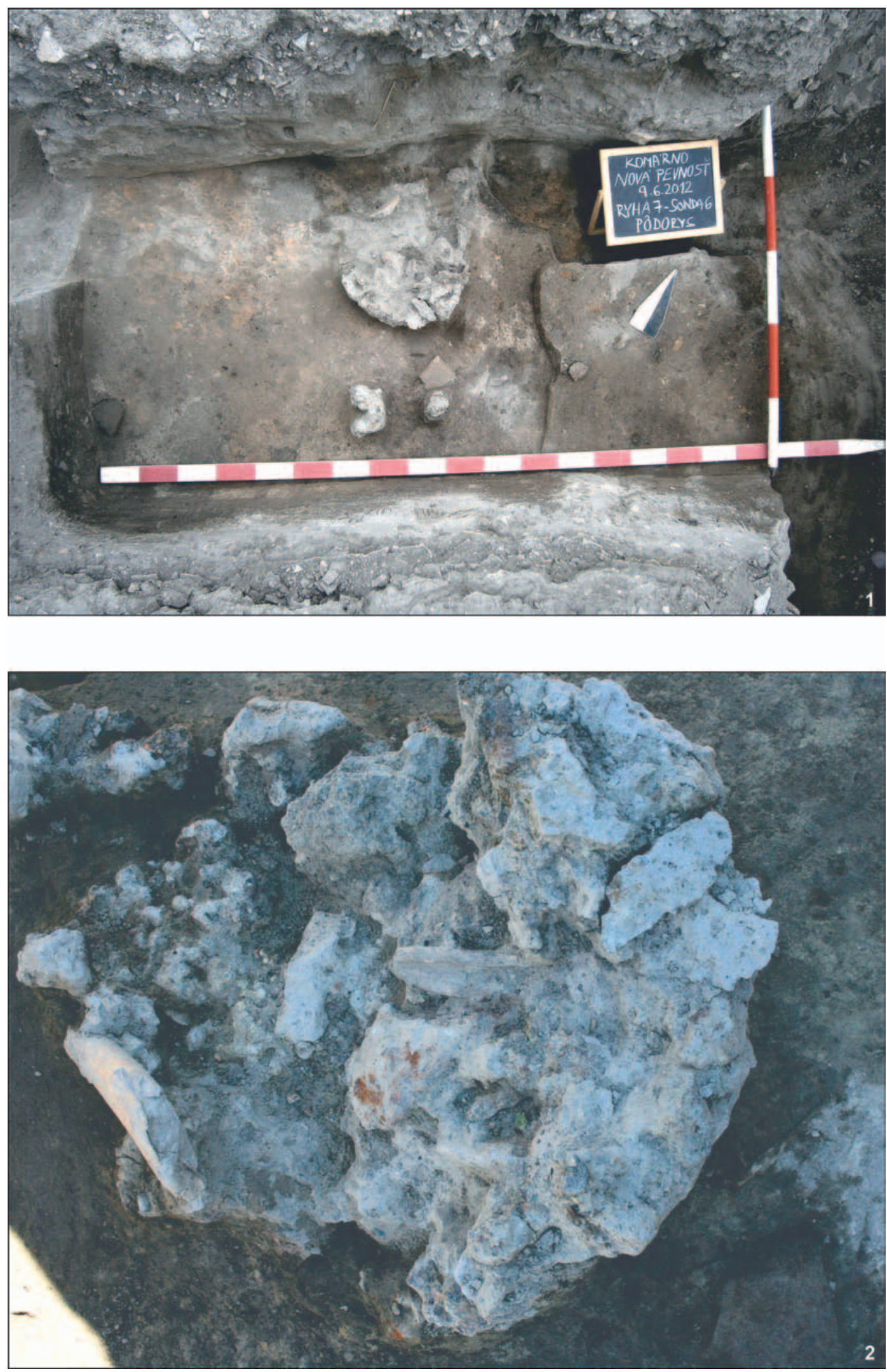

Fig. 4. Komárno, New Fortress site. Feature 6/12.1 - ground plan of the feature; 2 - detail of the iron cake left after melting. 
a.s.l.) and a settlement feature from the La Tène period $(1 / 19)$ were discovered in Trench 1 . Several features were documented in other parts of the trench; five of them $(2 / 19,4 / 19,10-12 / 19)$ can be also dated to the La Tène period by the obtained material.

7. Komárno, Stará pevnost' (Old Fortress) site.

During the rescue excavation by SAHI, o. z., settlement of the site from several historical periods was documented. The most remarkable settlement has been documented from the Eneolithic. In Section 2, a feature which can be dated to the La Tène period by pottery was identified. A large number of ceramic material from this period was also found in secondary sites (Jelinek/ Straková/Benková 2010). A fragment of a bottom from a situla-shaped pot with a stamp also comes from this site (Gere 2017, fig. 1: 6).

8. Komárno, the site at the confluence of the Danube and Váh rivers, i.e. on the northern side of the Slovak-Hungarian border, in today's Komárno. A depot of 34 Celtic coins was discovered in 1874 . The location where the coins were found is identified according to the description in the Saint Germain museum's catalogue (Hunkal Kolníková 1994, 49; Kolníková/Kolník 2004, 13).

\section{ANALYSIS \\ OF ARCHAEOLOGICAL SOURCES}

Based on the confirmed sites with finds from the La Tène period, we assume that it is a settlement agglomeration (Fig. 1; 2). We can find there settlement pits of various character, a battery of pottery kilns, possible remains of a metallurgical furnace or a production workshop as well as cultural layers rich in pottery material. This is the current state of research and it is only a question of time when other settlement features will be studied. All previously studied sites were investigated by means of rescue excavations, thus, there were no open-area or systematically focused excavations. However, the fact that older evidence of settlement is disturbed by massive intervention related to construction of features in the Middle Ages and Postmedieval period must be taken into consideration. The structures include an anti-Turkish invasion fortress, when the Old Fortress started to be built in 1546 on foundations of an older castle and the New Fortress started in 1658.

\section{Settlement features}

It was possible to detect several features and a rather rich cultural layer from the La Tène period. They are oval pits without more detailed identification which were probably used for working purposes. Their diameters vary between 100 and
$200 \mathrm{~cm}$ and they were sunken 150-160 $\mathrm{cm}$ below the terrain level. They contained mainly pottery (Pl. I-IV) and miniature artefacts (Fig. 6; Pl. V). Samples of fauna and flora were also taken; 16 samples for analysis of vegetal macroremains from the area of pottery kilns at Nádvorie Európy square were expertly evaluated (Hajnalová 2002, 55, 56).

\section{Production features}

\section{Pottery kilns}

During the rescue excavation carried out in 2000-2004 by P. Ratimorská and K. Pieta (most terrain works were done in 2000-2001) in the area of Nádvorie Európy square (Fig. 3), 6 pottery kilns were studied over an area of $130 \mathrm{~m}^{2}$ (Koštial 2004; Pieta 2008). During 2003, after interior walls had been built, the area was $62 \mathrm{~m}^{2}$. Investigation of the whole area was carried out in 2020 (Koštial 2021). These firing aggregates are in various stages of construction and reconstruction (they have not been completely processed and evaluated yet). The vertical stratigraphy of the site confirms that the large battery of kilns was not operating simultaneously. Firing could have been carried out simultaneously in max. four aggregates, although the pottery practice documented by ethnographic sources probably meant seasonal firing in one or two kilns (Koštial 2004). Sherds representing a group of high-quality wheel-made pottery come from the excavation's area and they also include goods with painted decoration. Hand-made so-called Dacian pottery is absent. Fragments of vessels representing high-quality wheel-made goods were found on the grate of kiln 1 . As for kiln 1, we suppose that it is the oldest one. Although painted goods come from the kilns, none was found in kiln 1 (Pl. II). In the final excavations in 2020 (Koštial 2021) a bronze fibula of Almgren 65 type $^{3}$ was discovered in the area in front of kiln 1, which is very important for dating of this battery of kilns. All of them are double-chamber vertical kilns which were - in central Europe - collected and evaluated by T. Mangel and R. Thér (2018, fig. 100). The kilns in Komárno are dated to the earlier phase of the Late La Tène period, LTD1. The find of the fibula, however, does not exclude possible existence (opening) of this space also in LTD2.

\section{Metallurgical furnace?}

When the New Fortress was investigated in 2012, feature no. 6/2012 was studied in furrow 7 (Fig. 4). It was located under the modern made-up ground,

\footnotetext{
3 The find is deposited in the Podunajské múzeum in Komárno.
} 


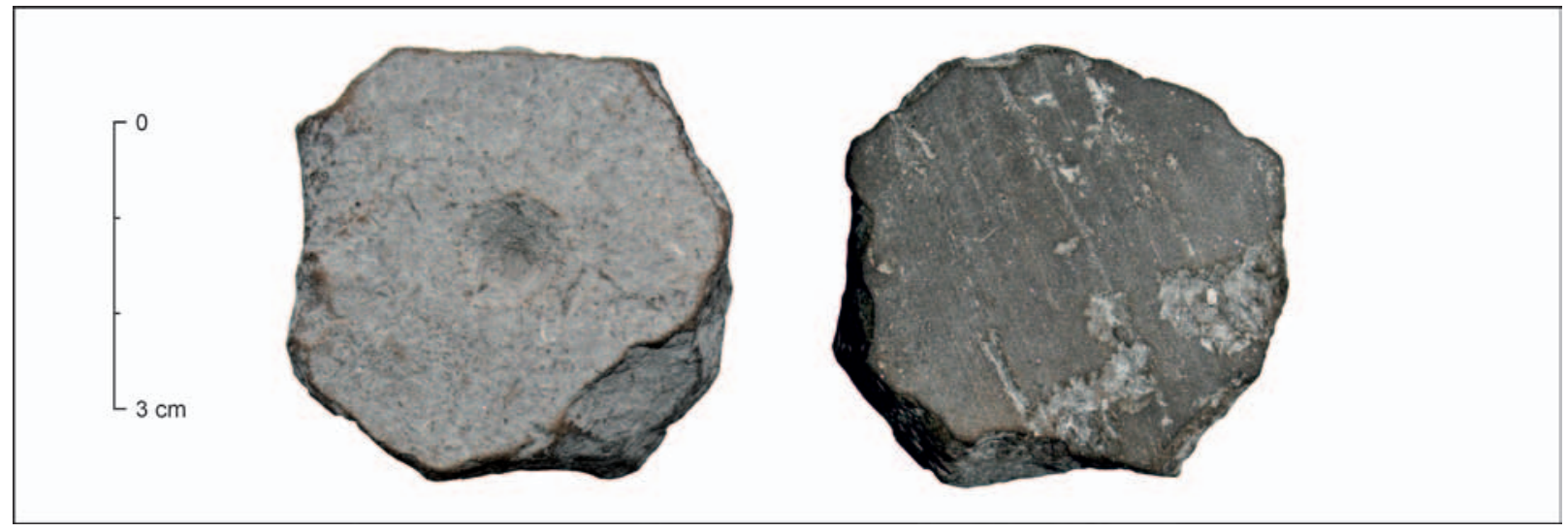

Fig. 5. Komárno, New Fortress site. Modified shard with a dimple (front and from behind).

$16-32 \mathrm{~cm}$ below the current terrain and its fill was made up by pale brown loam layer with clay and daub, continuing in a pale brown sandy layer. The bottom of the feature reached $103 \mathrm{~cm}$ deep from the current terrain (altitude $111 \mathrm{~m}$ a.s.l.). A large amount of iron slag (as much as $10 \mathrm{~kg}$ ), sherds, daub and individual animal bones come from its fill (Gere 2013, 90, pl. VI; IX). We assume that it is the bottom part of a metallurgical shaft furnace of a round shape with a 'slag cake' at the feature's bottom. The investigation confirmed that construction of the Old and New fortresses disturbed the upper layers from the La Tène period, which is suggested by numerous finds from that period, unique medieval pottery and finds of human bones found on the rampart of the fortress some of which might come from the terrain works in its interior. A fragment form a vessel body secondarily shaped into a disc comes from the rampart (Fig. 5). There is a dimple on its inside. The sherd's size is $4.8 \mathrm{x}$ $4.6 \mathrm{~cm}$ and it is $1.4 \mathrm{~cm}$ thick. The ceramic matter contains a low portion of graphite. In the central part of the sherd's inner side, there is a secondarily made dimple with smooth walls, narrowing in a funnel shape towards the bottom. The dimple is $1.1 \mathrm{~cm}$ wide and $0.5 \mathrm{~cm}$ deep. Such modified sherd of a vessel could have been used as a dosing plate for non-ferrous metals. Besided the melting pots and dosing plates, sherds of larger vessels were also adapted to dosing (Březinová 2007; Kolníková 2012). Nevertheless, we cannot exclude the possibility that the sherd shaped into a disc with the unfinished drilled hole might have been used as a spindle whorl in weaving. We have recorded such artefacts e.g. in Bratislava, Hradný vrch (Castle hill) site (Čambal 2004, 30, pl. LXV: 6). ${ }^{4}$

\section{A workshop?}

Two features (feature 1, 2) from the site of Park Anglia can be classified as production features. The author interpreted them on the basis of finds of iron slag, amount of graphite and burned layers as remains of production features (Ratimorská 1983, 212). Besides sherds (Pieta 2008, fig. 77: 1-13; 86: 1-11), where storage vessels with massive ruffs, bowls with everted rims, a situla with incompact horizontal combing, the finds included subtle bottle shapes and a bowl with inner wavy line, fragments of painted vessels and a Beltz J type bronze brooch (Pieta 2008, fig. 77: 14). However, detailed information on the features is absent. ${ }^{5}$

\section{Material culture}

This study deals with the finds from features and layers obtained by excavations and collection from the above mentioned sites. Most of them are pottery and - less frequently - various miniature artefacts. Samples of fauna and flora have also been taken from the studied layers and features, however, they have not been evaluated yet.

\section{Pottery}

Basic evaluation of pottery from two sites - Park Anglia and New Fortress - from excavation in 2012 has been published (Gere 2013; Pieta 2008, fig. 77). It is of high quality and painted pottery is also represented. The vessels are made on potter's wheel and they correspond with the shapes possibly

\footnotetext{
4 In case of the find from Komárno, the dimple is not located in the centre and the shape of the sherd itself is not circular. Natural science analyses could help us solve this problem.

${ }^{5}$ Only sherds are deposited in the Podunajské múzeum in Komárno.
} 


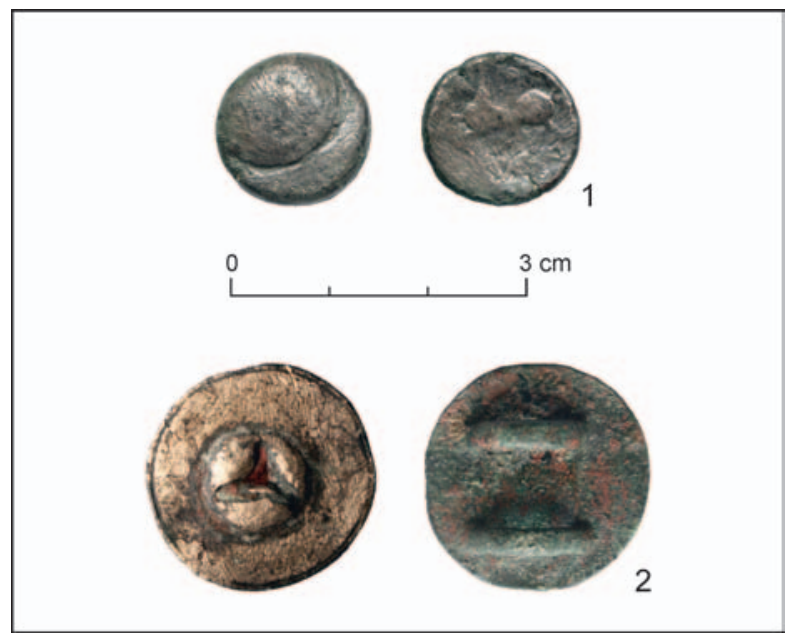

Fig. 6. Komárno, New Fortress site. 1 - copper coin of the Vel'ký Bysterec type - feature 2/19; 2 - strap loop with triskeles - feature 1/19.

datable to the end of the Middle La Tène period, stage LTC2, as late as the Late La Tène stage LTD1 and LTD2; we rely on the range of shapes from Bratislava, the castle, according to $R$. Čambal (2004, 203, 204, pl. LXVII; LXVIII). As far as the finds from Park Anglia are concerned, we can consider earlier dating to stages LTC2 and LTD1. A pot edge with claviform rim (Gere 2013, pl. IV: 3) typical of stage LTD2 also occurred in the collection from the New Fortress site (Čambal et al. 2014, 63-73; Čambal/ Kovár/Hanuš 2012). Such dating is supported by fragments of conical bowls with arcuately everted offset necks with S-shaped profiles of the Békásmegyer type with distinctly everted rims (Gere 2013, pl. IV: 2; VII: 2). In pottery, it is a rather recent element occurring in the transitional stage LTD1/D2 and in stage LTD2 (Čambal 2004, 28). Represented shapes include storage vessels with massive rims, a strainer (Gere 2013, pl. I: 5) and a conical lid (Gere 2013, pl. IV: 1). The so-called Dacian pottery was not found in these two collections. Such pottery was detected when research continued in 2019 (Gere/ Gereová 2019) at the New Fortress site in feature 2/19 (Pl. IV: $1-8$ ). In a pit with a circular groundplan which was detected just under the medieval layer, at the altitude of $111.09 \mathrm{~m}$, a large number of pottery representing a range of late La Tène shapes of high quality wheel-made vessels (Pl. I) as well as hand-made shapes with various plastic protuberances, the so-called Dacian pottery, was discovered. Other finds from the feature's fill are also very important for dating of the pottery. They include a bronze (copper?) coin, an iron haft (socket?), a whetstone and a tooled antler (Fig. 6: 1 ; Pl. V: 1, 3, 8). The pit's diameter is $160 \mathrm{~cm}$ and its depth is $196 \mathrm{~cm}$. High-quality pottery from bowls and bottle-shaped vessels with decoration in form of impressed circumferential wavy line and oblique bands arranged along the perimeter into triangles was found on the grate of kiln 1 at Nádvorie Európy square (PL. II). We assume that such vessels were fired in the kilns and chronologically, they belong mainly to the early phase of the Late La Tène period. Only three stamps on the bottoms of probably situla-shaped vessels come from Komárno. Based on the typology elaborated by I. Kappel (1969) and complemented by M. Čižmár and J. Meduna (1985), they belong to types 2 and 6a. According to analogies from well-dated finds from the site of Bratislava-Vydrica, such stamped vessels belong to stages LTD1 to LTD2 (Čambal) Kovár 2019, fig. 3).

\section{Vessels decorated with painting}

We have recorded 271 exemplars of painted pottery from the sites in Komárno. It is currently known from four sites: Anglia Park (22 exemplars), Nádvorie Európy square (138 exemplars), Old Fortress (8 exemplars exclusively from recent interventions) and New Fortress (103 exemplars; 56 of them come from feature 2/2019). The fragmentary condition of this material, unfortunately, often does not allow us to identify the original shape of the vessels. Plate III: $a-h$ presents samples of decorative motifs found in Komárno so far as well as the colour scale used for painted decoration (Pl. III: i-m). It was applied mainly on bottles, where short bulbous shape with arcuately everted and funnel-shaped mouth prevails (Pl. III: 7). A fragment of a funnel-shaped rim with applied white engobe can also be classified among bottles (Pl. III: 5). From other shapes, there are deep semiglobular bowls. Their decoration consisted of wider and narrower bands of red and white colour (Pl. III: 1, 4, 8, 9). Rared shapes with applied paint include conical bowls with S-shaped profiles. This shape is represented by areal red paint extending to the inner side of the rim (Pl. III: 9). In the La Tène period, paint has been documented almost exclusively on high-quality pottery (finely washed clay, high-quality firing). Painting was done by coloured clay engobes applied on vessels before firing (Čambal/Gregor 2008, 103-106; Repka 2020, 88). Easter Celtic painted decoration of pottery consisted of several basic colours, such as white, red and brown, black, or their shades - reddish brown, dark brown, greyish brown (sepia), brownish yellow, beige. The above mentioned elements of primary as well as secondary paint have been recently described and classified by I. Žernožičková (2017) 
on the basis of the collected finds from the Staré Hradisko oppidum in Moravia. It is obvious from the evaluation of pottery shapes and decorative motifs that the Late La Tène painted pottery from Komárno is not different from the traditional geometrical ornamentation of the eastern Celtic environment. The painted fragments can be attributed to bottle-shaped vessels, semiglobular and conical bowls, cups and lids. As for decoration, application of white and red engobes in form of horizontal bands and wavy lines is dominant, however, areal painting and application of a secondary ornament also occurs. Secondary ornaments are represented in the geometric zone by traditional elements - straight lines, wavy lines, zig-zag lines and grids. The pottery kilns of Komárno document presence of a workshop manufacturing these specific luxurious goods. On the basis of our current information, we assume the occurrence of painted pottery in the territory of Komárno mainly in stage LTD1, in a reduced form possibly as late as stage LTD2.

\section{Hand-made Dacian pottery}

Besides wheel-made pottery, hand-made vessels occur at the settlements from the La Tène period. In the Late La Tène period, this production is complemented with vessels decorated with various plastic protuberances and garlands. They are mainly barrel shapes or conical bowls and bowls with handles. They were found at two sites in the territory of Komárno-Kossuthovo námestie square (Pl. IV: 9) and the New Fortress in feature 2/19 (Pl. IV: 1-8). Analogous shapes come from the sites in the Nitra river basin, Nitra Castle, Nitra-Svätoplukovo námestie square and Nitra-Mikov Dvor and in Šurany-Nitriansky Hrádok (Bednár/Březinovál Ptáčková 2005; Březinová 2009; 2010; Březinová/Katkin 2004; Březinová/Ruttkay 2019).

\section{Miniature artefacts}

\section{Parts of garments and jewels}

- Brooches/fasteners

A bronze brooch of the Beltz J type is known from the Park Anglia site (Pieta 2008, 77: 14). Details of its find context are unknown. We suppose that it was part of fill in production features (Ratimorská 1983, 212). More exact dating of these brooches, also on the basis of finds from Staré Hradisko
(ČižmářlČižmářová/Meduna 2018, 43) and Manching (Gebhard 1991, 35, pl. 12: 203, 204), is limited by younger stage LTD1. Dating is confirmed by other finds from Mostná ulica street in Nitra (Březinovál Samuel 2007, fig. 43) and Devín (Pieta/Zachar 1993, fig. 115: 9).

Two iron brooches from feature 4/19 from the New Fortress site were found in a considerably corroded condition. After their restoration ${ }^{6}$, they can be classified into individual types. The iron brooch with one-piece construction and long spring $(6+7)$ is $52 \mathrm{~mm}$ long and the coils' span is $36 \mathrm{~mm}$. There is a stud on the bow (Pl. V: 5).

According to the map of occurrence of such brooches (Pieta 2008, fig. 25: B), they are associated mainly with the Púchov environment in Slovakia. Their dating to LTC2 and LTD1 has been confirmed at the oppida in Manching (Gebhard 1991, type 22 and 23) and Staré Hradisko (ČižmářlČižmárovál Meduna 2018, 116).

The second iron brooch belongs to wire brooches with one-piece construction (Pl. V: 6). The total length of the brooch is $46 \mathrm{~mm}$, the bow's height is $20 \mathrm{~mm}$. Due to damage by corrosion, it is difficult to interprete other parts of the brooch. The spring is simple, two-sided. Bronze variants of such brooches are again associated with the Púchov territory and sites like Dolný Kubín-Vel’ký Bysterec, Liptovská Sielnica-Liptovská Mara, Jalovec, Jánovce-Machalovce, Vyšný Kubín (Pieta 2008, fig. 25: A). Iron variants come e.g. from Folkušová (Pieta 2008, fig. 26: 1) or the oppidum of Staré Hradisko (Čižmár̆l ČižmářoválMeduna 2018, 233).

A bronze brooch of Almgren 65 type was discovered at Nádvorie Európy square in the loading area of kiln 1. ${ }^{7}$ Brooches of Late La Tène construction with frame catchplates and asymetrically decorated bows and breaks decorated with plastic ribs often occur at oppida in the Middle Danube region and Czech-Moravian territory, where their iron variant prevails (ČižmářlČižmářová/Meduna 2018, 49). Dating falls to the interface between stages LTD1 and LTD2.

\section{Lithic artefacts}

A whetstone with quadrangular base and its upper part well modified for grip comes from the New Fortress, feature 2/19 (Pl. V: 3). Material: sandstone. Whetstones are common in settlement and production features during the whole La Tène period (Illášová 2000, 225; Pieta 2008, 74).

\footnotetext{
6 We wish to thank Mgr. M. Knoll.

7 As the material has not been published yet, we do not publish the brooch without the other author's consent.
} 


\section{Metal artefacts}

A strap loop (patch) from the New Fortress, feature 4/19, is made of bronze (Fig. 6: 2; Pl. V: 4). It is annular, with diameter of $22 \mathrm{~mm}$. In the mid$\mathrm{dle}$, there is a disc with diameter of $12 \mathrm{~mm}$. Along the rim of the disc, there is a fine circumferential recess. The disc's body is divided into three parts, so-called triskeles, by a recess. On the back, there are two evenly located attachment rings. Based on analogies, this artefact was part of decoration of horse harness (Pieta 2008, fig. 113: 1-11; Schönfelder 2002).

An iron haft (socket?) with unknown function (Pl. V: 2) as well as an iron sleeve? also come from feature 2/19 at the New Fortress site (Pl. V: 1).

\section{Antler artefacts}

A tooled antler artifact, possibly a functional tool, comes from feature 2/19 at the New Fortress site (Pl. V: 8). Almost complete antlers (of a deer?) with cut-off side tines come from the same site, feature 4/19 (Pl. V: 7). The preserved part is $800 \mathrm{~mm}$ long.

Tooled bone and antler artifacts are not frequently found at sites from the La Tène period in Slovakia. For instance, only 16 exemplars were found at only three settlements at the settlement agglomeration in Nitra (Březinová 2014). This could imply lower interest in this type of material, lack of it or, possibly, that the local population did not adopt the complicated technique of processsing this raw material. Newer finds were processed from the settlement in Bratislava, Zlaté piesky site (Hrnčiarik 2019, fig. 1).

\section{Coins}

A hoard of Celtic coins comes from today's territory of Komárno. As the exact find context is unknown, we present the site with a question mark (Fig. 1: 8?; 2: 8?). As stated by E. Kolníková (Kolníková/Kolník 2004, 14), K. Castelin published a hoard of Celtic coins deposited in Musée des Antiquiteés Nationales in Saint-Germain-en Laye near Paris in 1970. According to his information, it was discovered in 1876. It was enlisted in the catalogue of the numismatic collection in that year, with the information '... hoard was discovered in Komárno, the capital town of Komárno County in Žitný ostrov river island near the confluence of the Danube and Váh rivers, 1876' (Kolníková/Kolník 2004, 14). K. Castelin was not sure which Komárno the find comes from. He did not know whether it was the left or the right side of the Danube or whether the hoard was found somewhere in its vicinity. His doubts, however, are dispelled by the information in the catalogue of the museum in Saint-Germain - 'it was discovered at Žitný ostrov river island, near the confluence of the Danube and Váh rivers', i.e. on the northern side of the Slovak-Hungarian border, in today's Komárno (Hunka/Kolníková 1994, 49, no. 21). According to E. Kolníková, this depot is a great contribution to solution of the topic of the Vel'ký Bysterec type of coins, although this type is only represented by one exemplar in the hoard from Komárno. This coin was included in a hoard of 33 other coins of the Szöny type (Kolníková/Kolník 2004, tab. 4). It is the first hoard with such composition and the first common occurrence of tetradrachm of the Vel'ký Bysterec type and the above mentioned miniature coins. They suggest contacts - probably mercantile - of the La Tène settlement in the area of Komárno with the settlement environment of the Púchov culture in northern Slovakia. Its direction was given by the Váh river or its contributaries (KolníkoválKolník 2004). Miniature coins similar to those in the hoard from Komárno were found at the neighbouring site of Komárom-Szőny (Kom. Komárom-Esztergom) in Hungary. They are deposited in the Hungarian National Museum in Budapest, the year of its discovery is 1910. The hoard includes a golden Boian $1 / 3$ stater. The authors are considering existence of a Late La Tène mint in the territory of today's Komárno, where these miniature coins were minted shortly after the first half of the $1^{\text {st }} \mathrm{c}$. BC (Kolníkovál Kolnik 2004, 15).

Another coin of the Vel'ký Bysterec type (Fig. 6: 1) comes from more recent excavations. It comes from feature 2/19 at the New Fortress site. The coin is a copper didrachm of the Vel'ký Bysterec type and weighs $5 \mathrm{~g}$. It is another document of occurrence of these north Slovak coins in the south of Slovakia. They arrived there probably along the Váh trade route $^{8}$. The fact that it consists of copper, might be associated with the fact that from the mid $2^{\text {nd }}-1^{\text {st }} c$. BC mints dealt with minting of silver, but golden and copper coins were minted in some regions as well (Kolníková/Bakoš/Pauditš 2014, 156).

\section{Graphite}

Interesting finds include a lump of raw graphite from the site of New Fortress, feature 1/2019. The feature's oval groundplan was detected in sector 1 . The feature is associated with layer 3 (cultural layer

\footnotetext{
8 We wish to thank PhDr. E. Kolníková, DrSc., for identification. Date of identification: 11. 4. 2019.

9 According to identification by Mgr. M. Knoll, it is bronze with high proportion of copper and with admixture of tin.
} 
from the La Tène period). Inventory: pottery from the La Tène period, a bronze strap loop, a lump of graphite, daub. The graphite raw material was probably used at pottery production. It is also mentioned in the production feature from Anglia Park, however, more detailed material for verification of this find is absent. The importance of graphite in the La Tène period is dealt with in several studies which are summarized in a monograph by $D$. Repka (2020, 98-102).

\section{FINAL REFLECTIONS}

The aim of this article was to present sufficiently documented material of the settlement of Komárno at the end of the Middle and during the Late La Tène period. Despite the fact that systematic archaeological investigations focused on settlement in the La Tène period have not been caried out, we were able to summarize multiple evidence of the exceptional character of this strategical point in the south of Slovakia.

We follow from the fact that similarly to the importance of this place in building an anti-Turkish invasion fortress in the $16^{\text {th }}-17^{\text {th }}$ c., it was very important for the local people in the La Tène period. Unfortunately, such intense earth works probably destroyed older settlement. In spite of this, even smaller rescue projects always confirm evidence of its existence. Settlement pits, massive layers with numerous material are the evidence that a large settlement, possibly a central settlement, must have been located in this area, with documents of production and of course with live contacts with the surrounding world. The favourable geographical location on the confluence of two great rivers - the Danube and Váh - helped Komárno to become a crucial strategical point. Features detected at individual sites in the town confirm existence of manufacture focused on metallurgy (New Fortress, Park Anglia) and pottery production (Nádvorie Európy square). We suppose that the vessels manufactured there travelled along the Váh route northwards and along the Danube route southwards and westwards by means of busy trade. These contacts are indirectly confirmed by finds of miniature artefacts, such as fasteners and coins, mainly two coins of the Vel'ký Bysterec type. Based on metal finds and pottery, the La Tène settlement in Komárno can be dated to the end of the $2^{\text {nd }}$ and to the $1^{\text {st }} \mathrm{c}$. BC. The quality and range of artefacts from the La Tène period confirm the assumed importance of the territory of Komárno in that period and possible presence of a Late La Tène centre. Special attention should be paid to the numerous Late La Tène painted goods which have multiple analogies at Late La Tène settlements of central character, such as Nitra (the sites of the castle and Mikov dvor), Šurany-Nitriansky Hrádok, Bratislava, Esztergom, Budapest. Functionality of pottery kilns is dated - also due to absence of thick, so-called Dacian, pottery - to LTC2/D1-D1. Probably identically, settlement existed at other sites too, but it survives as late as LTD2, or the turn of eras.

Several other interesting finds which could be associated with the settlement in Komárno in the Late La Tène period are contained in the collections of the Podunajské múzeum in Komárno. Unfortunately, their find contexts are absent. There is a fragment of a late type of a glass bracelet. Its colour is dark blue, almost black (Gebhard 1989). It is a Jezerine type brooch (Lamiová-Schmiedlová 1961, pl. XVIII: 3) whose origin must be searched for in the territory of Central Italy and the East Alpine Arc. The limit values of its dating are 20 BC-20 AD. It comes from Bratislava, Hlavné námestie 7 square (Musilová/Lesák 1996, pl. II: 3) and Michalská ulica street (Vrtel 2009, pl. 1: 6). As far as more extensive contacts with the Mediterranean territory are concerned, we must mention an interesting artefact mentioned at evaluation of Mediterranean imports from the oppidum in Tř́sov (Kysela/Danielisová/Militký 2014, 579). It is part of a bronze ladle, simpula, dated to the last third of the $2^{\text {nd }} \mathrm{c}$. BC-third quarter of the $1^{\text {st }} \mathrm{c}$. BC. 


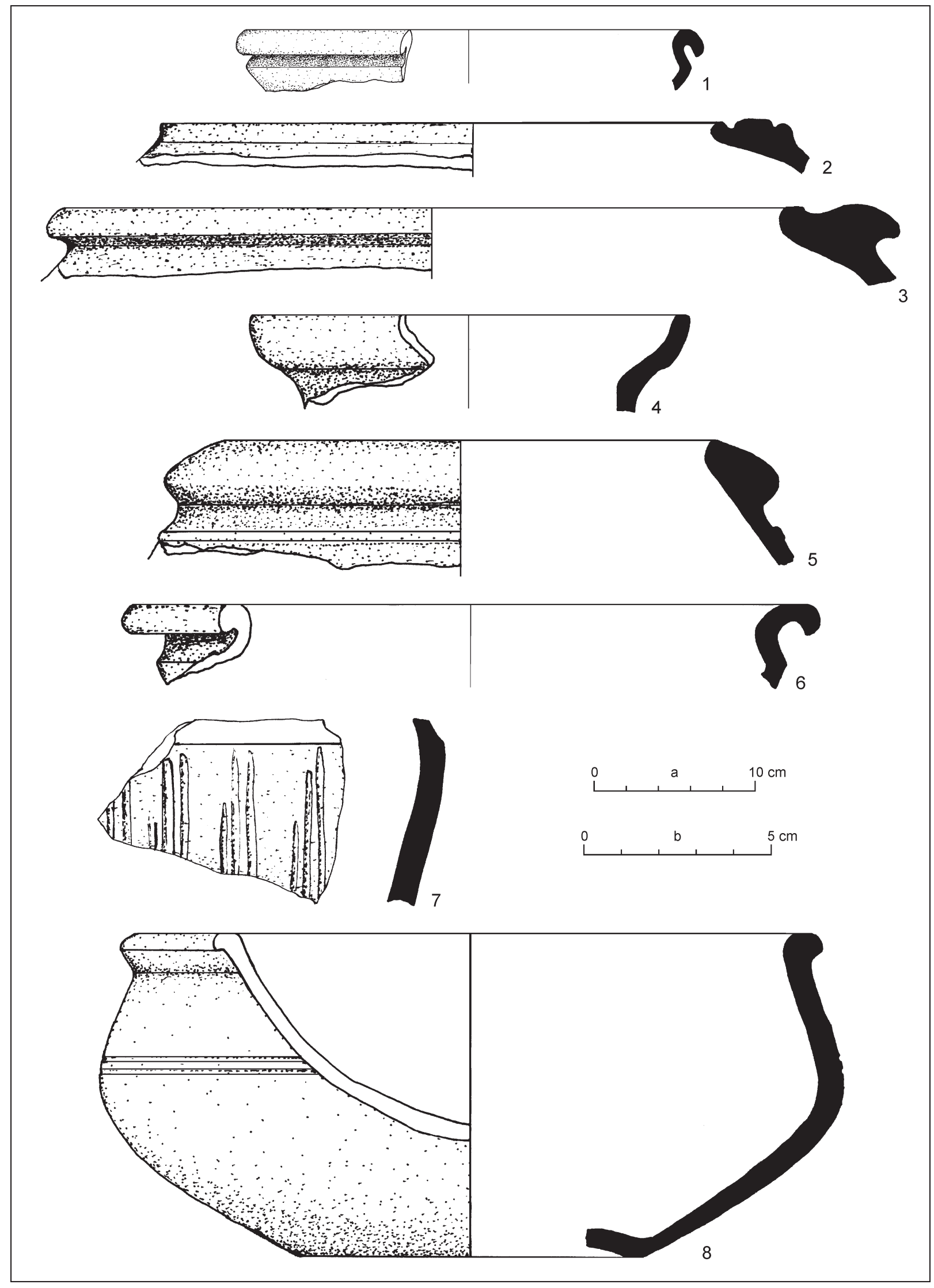

Pl. I. Komárno, New Fortress site, feature 2/19. Selected pottery. Scale: a -1-3; b-4-8. 


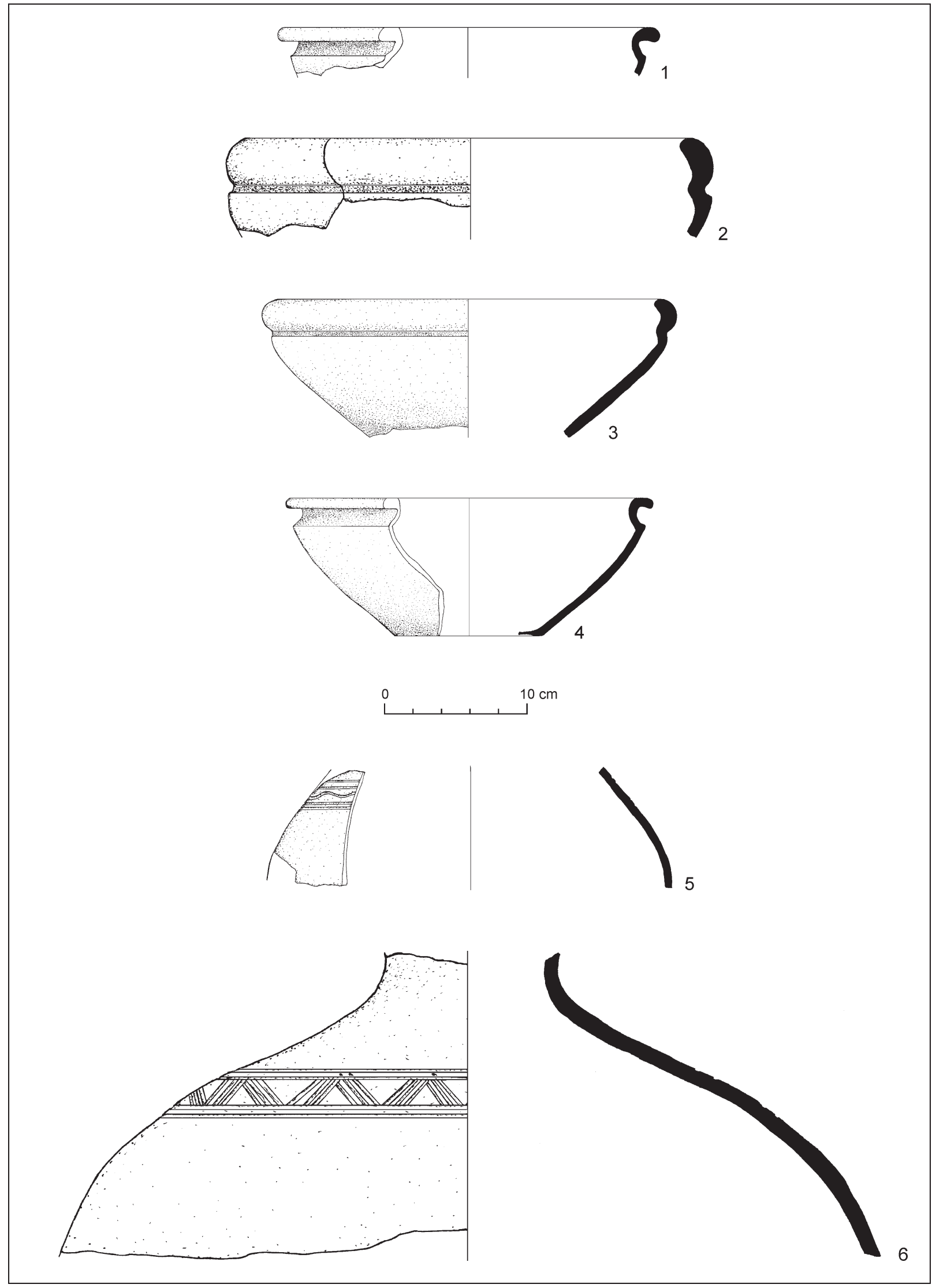

Pl. II. Komárno, Nádvorie Európy square site. Kiln 1. Selected pottery from the grate (2004). 


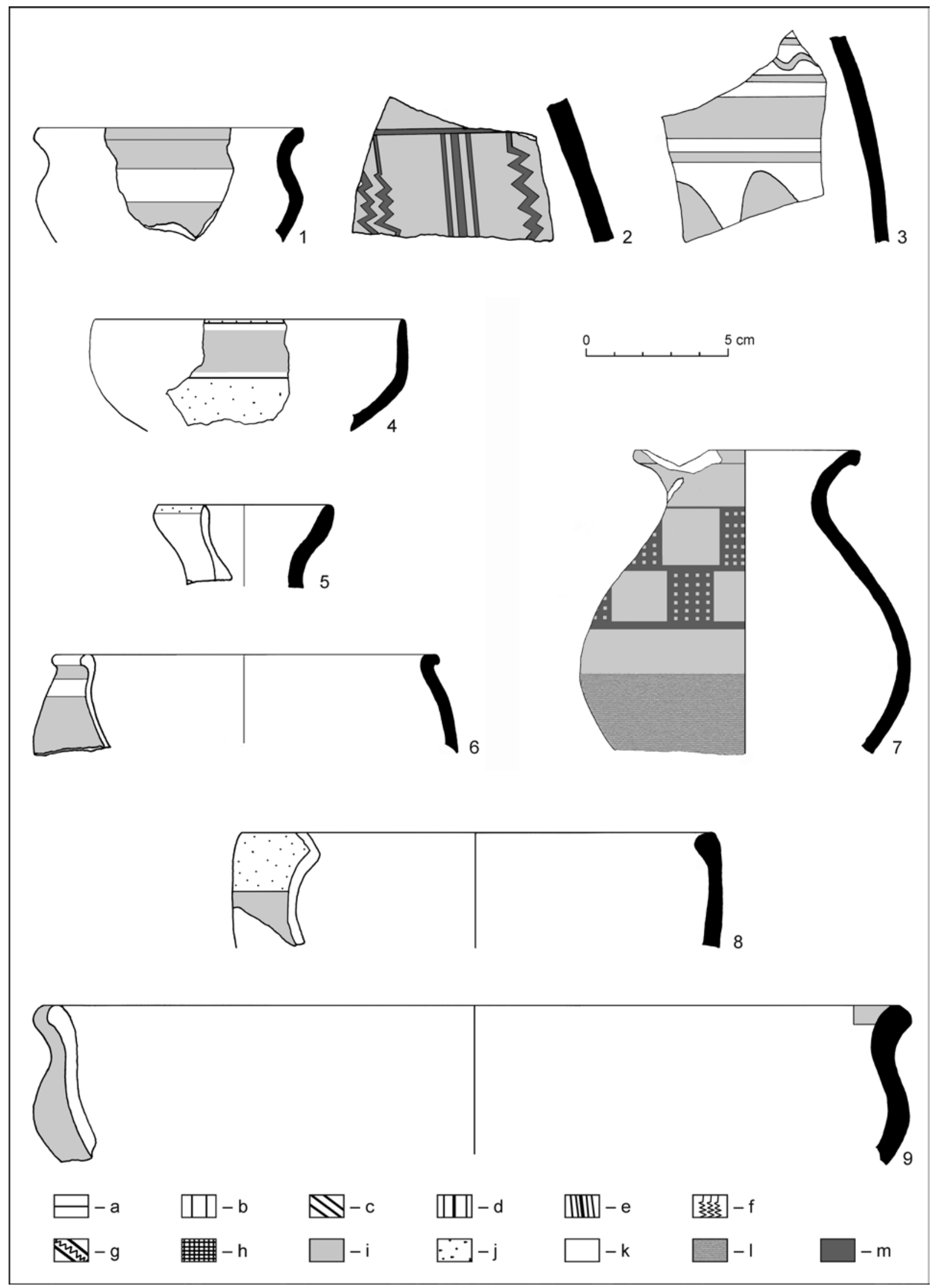

Pl. III. Komárno, New Fortress site. Selected painted pottery. Legend: a-h - samples of decorative motifs; $\mathrm{i}-\mathrm{m}$ - colour scale (i - red; $\mathrm{j}$ - no paint; $\mathrm{k}$ - white; 1 - brown; $\mathrm{m}$ - sepia pattern). 


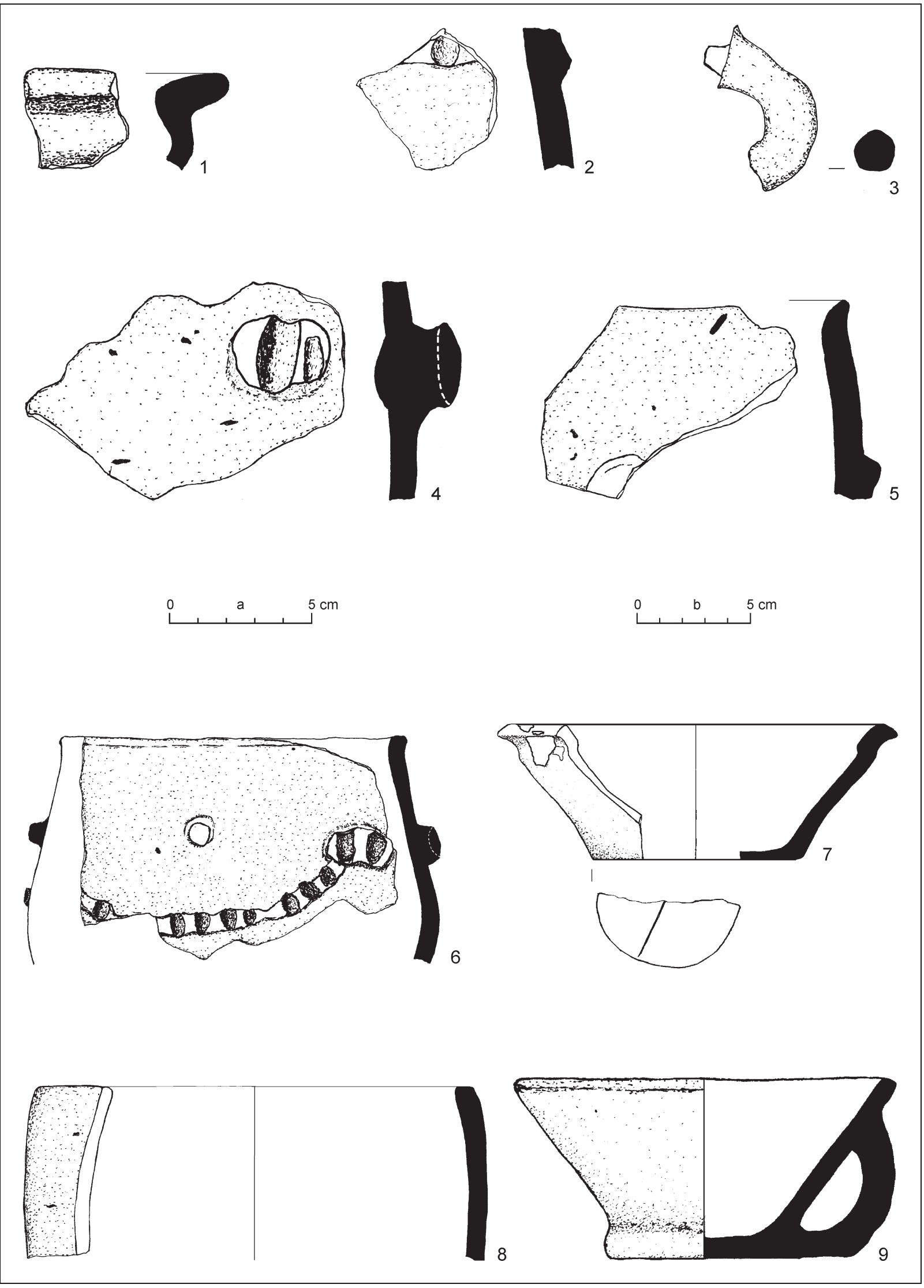

Pl. IV. Komárno. Selected Dacian pottery. 1-8 - New Fortress site, feature 2/19; 9 - Kossuthovo námestie square site, feature 107D/2011. Scale: $\mathrm{a}-1-5 ; \mathrm{b}-6-9$. 


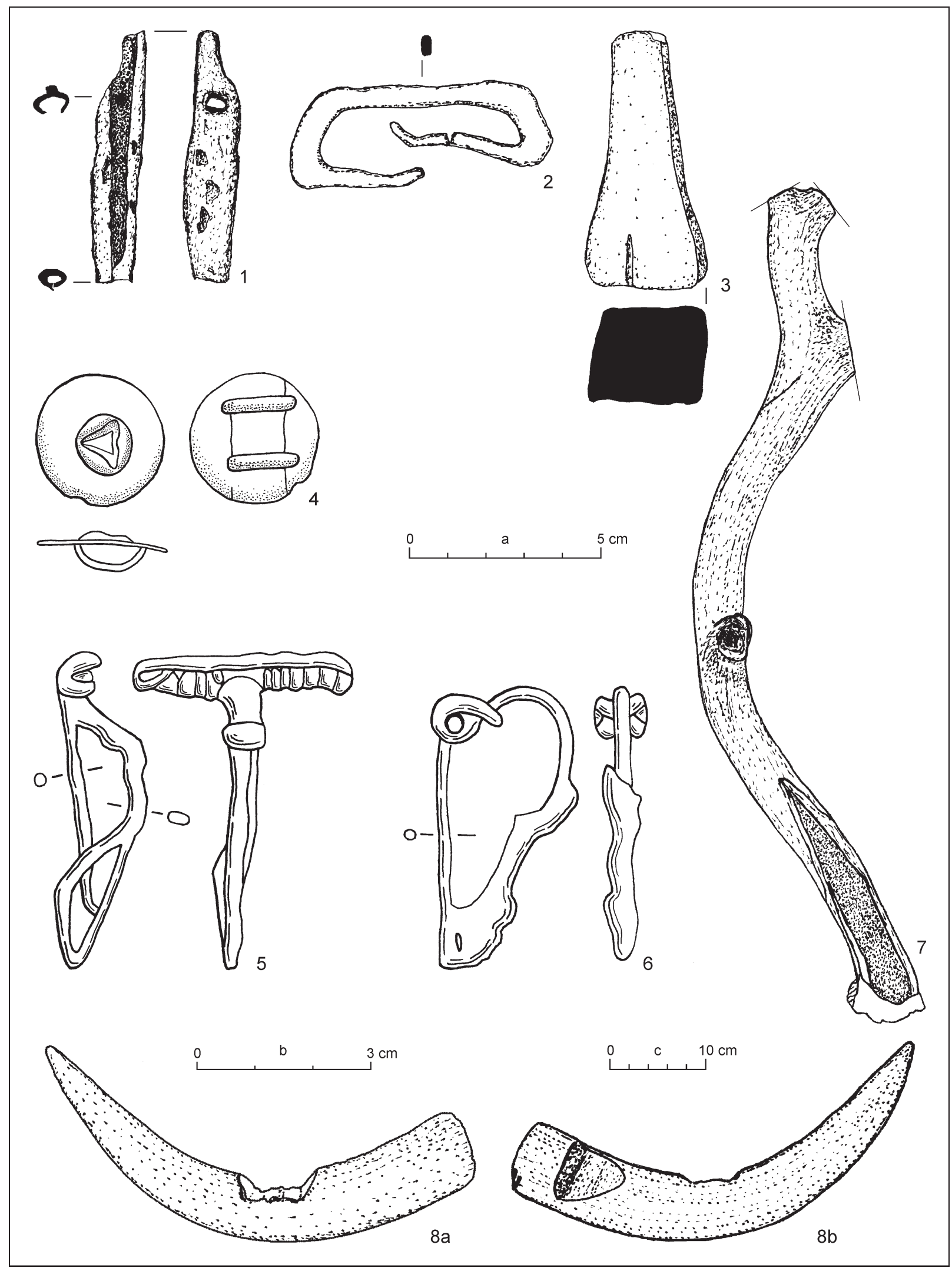

Pl. V. Komárno, New Fortress site. Miniature artefacts. 1 - iron socket (haft?), feature 2/19; 2 - iron strap loop, feature 2/19; 3 - whetstone, feature 2/19; 4 - bronze strap loop with triskeles, feature 1/19; 5 - iron brooch with multiple spring, feature 4/19; 6 - iron brooch, feature 4/19; 7 - antlers (semifinished product), feature 4/19; 8 - tooled antler artefact, feature 2/19. Scale: $a-1-3,8 ; b-4-6 ; c-7$. 


\section{BIBLIOGRAPHY}

Bednár 2006 - P. Bednár: Záchranný archeologický výskum bývalého kláštora jezuitov v Komárne. AVANS 2004, 2006, 33-35.

Bednár/Březinová/Ptáčková 2005 - P. Bednár/G. Březinová/ S. Ptáčková: Neskorolaténske osídlenie hradného návršia v Nitre. Študijné zvesti AÚ SAV 37, 2005, 115-185.

Bednár/Kvasnicová/Ratimorská 2005 - P. Bednár/M. Kvasnicová/P. Ratimorská: Komárno - bývalá rezidencia a kolégium jezuitov. Predbežná správa o výsledkoch archeologického a umelecko-historického výskumu. Archaeologia historica 30, 2005, 149-163.

Březinová 2007 - G. Březinová: Münzprägungbeweis in der latènzeitlichen Siedlung Nitra-Sindolka? Slovenská numizmatika 18, 2007, 31-40.

Březinová 2009 - G. Březinová: Neskorolaténske osídlenie Nitry. In: M. Karwowski/E. Droberjar (eds.): Archeologia Barbarzyńców 2008. Powiazania i kontakty w świecie barbarzyńskim. Materiaty z IV Protohistorycznej Konferencji Sanok, 13-17 października 2008. Collectio Archaeologica Ressoviensis 13. Rzeszów 2009, 55-70.

Březinová 2010 - G. Březinová: Sídlisko z neskorolaténskej polohy Zámeček v Šuranoch, Nitrianskom Hrádku. In: J. Beljak/G. Březinová/V. Varsik (eds.): Archeológia barbarov 2009. Hospodárstvo Germánov, sídliskové a ekonomické štruktúry od neskorej doby laténskej po včasný stredovek. Zborník referátov z 5. protohistorickej konferencie. Nitra 21.-25. septembra 2009. Archaeologica Slovaca Monographiae. Communicationes 10. Nitra 2010, 113-130.

Březinová 2014 - G. Březinová: La Tène Bone and Antler Artefacts from Nitra. In: S. Berecki (ed.): Iron Age Crafts and Craftsmen in the Carpathian Basin. Proceedings of the International Colloquium from Târgu Mureş, 10-13 October 2013. Bibliotheca Mvsei Marisiensis. Seria Archaeologica 7. Cluj-Napoca 2014, 191-198.

Březinová/Katkin 2004 - G. Březinová/S. Katkin: Sídliskový objekt z neskorej doby laténskej v Nitre-Malom seminári. Študijné zvesti AÚ SAV 36, 2004, 115-176.

Březinová/Samuel 2007 - G. Březinová/M. Samuel a kolektív: "Tak čo, našli ste niečo?" Svedectvo archeológie o minulosti Mostnej ulice v Nitre. Nitra 2007.

Březinová/Ruttkay 2019 - G. Březinová/M. Ruttkay: A Late La Tène feature from Nitra-Svätoplukovo námestie square, Slovakia. In: P. C. Ramsl/K. Rebay-Salisbury/ P. Trebsche (Hrsg.): Schichtengeschichten. Festschrift für Otto H. Urban. Universitätsforschungen zur Prähistorischen Archäologie 328. Bonn 2019, 163-173.

Čambal 2004 - R. Čambal: Bratislavský hradný vrch-akropola neskorolaténskeho oppida. Zborník SNM. Archeológia. Suplementum 1. Bratislava 2004.

Čambal et al. 2014 - R. Čambal/I. Bazovský/G. Březinová/ B. Kovár/M. Karwowski: Problematika hrncov s tzv. „kyjovitým“ okrajom zo záveru neskorej doby laténskej v stredodunajskom priestore. In: B. Komoróczy (ed.).: Sociální diferenciace barbarských komunit ve světle nových hrobových, sídlištních a sběrových nálezů (Archeologie barbaru 2011). Spisy Archeologického ústavu AV ČR Brno 44. Brno 2014, 63-73.

Čambal/Gregor 2008 - R. Čambal/M. Gregor: Engoby a pigmenty neskorolaténskej keramiky z bratislavského oppida. Zborník SNM 102. Archeológia 18, 2008, 95-107.

Čambal/Kovár 2019 - R. Čambal/B. Kovár: Značky na nádobách z doby laténskej na príklade lokality Bratisla-
va-Vydrica. In: I. Bazovský/G. Březinová (eds.): L’udia a hory - archeologická perspektíva. Interakcie l’udských spoločenstiev horských a podhorských oblastí západného Slovenska. Zborník SNM. Archeológia. Suplementum 12. Bratislava - Nitra 2019, 179-188.

Čambal/Kovár/Hanuš 2012 - R. Čambal/B. Kovár/M. Hanuš: Typológia neskorolaténskej keramiky z Bratislavy-Vydrice. In: G. Březinová/V. Varsik (eds.): Archeológia na prahu histórie. Kživotnému jubileu Karola Pietu. Archaeologica Slovaca Monographiae. Communicationes 14. Nitra 2012, 117-136.

Čižmář/Čižmářová/Meduna 2018 - M. Čižmář/J. Čižmářová/ J. Meduna: Nemčice a Staré Hradisko. Spony - Němčice und Staré Hradisko. Fibeln. Brno 2018.

Čižmář/Meduna 1985 - M. Čižmář/J. Meduna: Značky na dnech laténské keramiky na Moravě. Památky archeologické 76, 1985, 78-100.

Gebhard 1991 - R. Gebhard: Die Fibeln aus dem Oppidum von Manching. Stuttgart 1991.

Gere 2013 - M. Gere: Záchranný archeologický výskum Komárno-„,Nová pevnost”. Iuxta Danubium 15, 2013, 87-108.

Gere 2017 - M. Gere: Značky na dnách grafitových nádob z doby laténskej v zbierke Podunajského múzea v Komárne. In: A. Csuthy/P. Vanya (eds.): Mérföldkövek Mílniky 2015-2017. Komárno 2017, 100-107.

Gere/Gereová 2019 - M. Gere/M. Gereová: Komárno-Nová pevnost', okres Komárno. "Novostavba schodiska do suterénu Kasárne z exteriéru“. Komárno 2019. Výskumná dokumentácia. Archív Podunajského múzea Komárno 3/19. Unpublished.

Hajnalová 2002 -E. Hajnalová: Rastlinné makrozvyšky analyzované v roku 2001. AVANS 2001, 2002, 55-58.

Hrnčiarik 2019 - E. Hrnčiarik: La Tène bone and antler artefacts from Bratislava Zlaté Piesky. In: N. Beljak Pažinová/ D. Repka (red.): Sedem kruhov Jozefa Bujnu. Studia Historica Nitriensia 23. Supplementum 2. Nitra 2019, 449-456. DOI: https://doi.org/10.17846/SHN.2019.23.S.449-456

Hunka/Kolníková 1994 - J. Hunka/E. Kolníková: Nálezy mincí na Slovensku IV. Nitra 1994.

Illášová 2000 - L'. Illášová: Steinartefakte aus der latènezeitliche Siedlung in Nitra-Šindolka. In: G. Březinová: NitraŠindolka. Siedlung aus der Laténzeit. Katalog. Archaeologie Slovaca Monographie. Catalogi 8. Nitra - Bratislava 2000, 335-338.

Jelínek/Straková/Benková2010-P. Jelínek/L. Straková/M. Benková: Komárno, okres Komárno "Stará pevnost”. Komárno 2010. Výskumná dokumentácia. Slovenský archeologický a historický inštitút - SAHI o. z. Bratislava 2010. Archív Krajského pamiatkového úradu Nitra KN/T-0009. Unpublished.

Jelínek/Teslíková/Gere 2011 - P. Jelínek/T. Teslíková/M. Gere: Revitalizácia centrálnej mestskej časti - Kossuthovo námestie. Komárno 2011. Výskumná dokumentácia. Slovenský archeologický a historický inštitút - SAHI o. z. Bratislava 2011. Archív Krajského pamiatkového úradu Nitra KN/T-0058. Unpublished.

Kappel 1969 - I. Kappel: Die Graphittonkeramik von Manching. Die Ausgrabungen in Manching 2. Wiesbaden 1969.

Kolníková 2012 - E. Kolníková: K technike a technológii v keltskom mincovníctve - nálezy zo Slovenska. $\mathrm{Nu}$ mismatický sborník 26, 2012, 31-57. 
Kolníková/Bakos/Pauditš 2018 - E. Kolníková/F. Bakos/ P. Pauditš: Zdroje kovu v keltských mincovniach na Slovensku. Zborník SNM 112. Archeológia 28, 2018, 141-304.

Kolníková/Kolník 2004 - E. Kolníková/T. Kolník: Mince a spony - depot z neskorolaténskeho hradiska Rochovica pri Žiline (numizmaticko-archeologické súvislosti). Slovenská archeológia 52, 2004, 1-35.

Koštial 2004 - J. Koštial: Komárno - Nádvorie Európy. Technologická a funkčná analýza komplexu hrnčiarskych pecí z doby laténskej. Diplomová práca. Univerzita Konštantína Filozofa v Nitre. Filozofická fakulta. Katedra archeológie. Nitra 2004. Online available at: https://www.academia.edu/6957507/Kom\%C3\%A1rno_ N\%C3\%A1dvorie_Eur\%C3\%B3py._Technologick\% C3\%A1_a_funk\%C4\%8Dn\%C3\%A1_anal\%C3\%BDza_ komplexu_hrn\%C4\%8Diarskych_pec\%C3\%AD_z_ doby_lat\%C3\%A9nskej._Nitra_2004

Koštial 2021 - J. Koštial: Komárno, Nádvorie Európy. Komárno 2021. Výskumná dokumentácia. In prepare.

Kysela/Danielisová/Militký 2014 - J. Kysela/A. Danielisová/ J. Militký: Středomorské importy z oppida Třísov. Nálezy z povrchové prospekce s detektory kovů v letech 2007-2013. Archeologické rozhledy 66, 2014, 567-608.

Lamiová-Schmiedlová 1961 - M. Lamiová-Schmiedlová: Spony z doby rímskej na Slovensku. Študijné zvesti AÚ SAV 5, 1961, 7-142.

Mangel/Thér 2018 - T. Mangel/R. Thér: Laténské hrnčířské pece ve střední Evropě. Hradec Králové 2018.

Miklós/Hrnčiarová 2002 - L. Miklós/T. Hrnčiarová (eds.): Atlas krajiny Slovenskej republiky. Bratislava - Banská Bystrica 2002.

Musilová/Lesák 1996 - M. Musilová/B. Lesák: Neskorolaténske osídlenie na Hlavnom námestí č. 7. v Bratislave. Zborník SNM 90. Archeológia 6, 1996, 87-105.

Manuscript accepted 3. 6. 2021

Translated by Viera Tejbusová

doc. PhDr. Gertrúda Březinová, CSc.

Archeologický ústav SAV

Akademická 2

SK - 94921 Nitra

gertruda.brezinova@savba.sk
Pieta 2008 - K. Pieta: Keltské osídlenie Slovenska. Mladšia doba laténska. Archaeologica Slovaca Monographiae. Studia 11. Nitra 2008.

Pieta/Zachar 1993 - K. Pieta/L. Zachar: Mladšia doba železná (laténska). In: T. Štefanovičová (zost.): Najstaršie dejiny Bratislavy. Bratislava 1993, 143-209.

Ratimorská 1980 - P. Ratimorská: Archeologické prieskumy a nálezy v okrese Komárno. AVANS 1978, 1980, 226-228.

Ratimorská 1983 - P. Ratimorská: Záchranné výskumy a prieskumy v okrese Komárno. AVANS 1982, 1983, 211-214.

Repka 2020 - D. Repka. Laténska keramika ako predmet štúdia. Vysokoškolská učebnica. Nitra 2020.

Schönfelder 2002 - M. Schönfelder: Das spätkeltische Wagengrab von Boé (Dép. Lot-et Garonne). Studien zu Wagen und Wagengräbern der jüngeren Latènezeit. RömischGermanisches Zentralmuseum. Monographien 54. Mainz 2002

Varjú 2009 -Z. Varjú: Inžinierske siete ústrednej peonosti-Vodovod a kanalizácia - IG prieskum. Správa z geologického prieskumu areálu pevnosti. Komárno 2009. Mestský úrad Komárno. Unpublished.

Venclová 2016 - N. Venclová: Němčice and Staré Hradisko. Iron Age Glass and Glass-working in Central Europa. Praha 2016.

Vrtel 2009 - A. Vrtel: Neskorolaténske oppidum v Bratislave remeselná výroba, výmena a obchod. Dizertačná práca. Archeologický ústav Slovenskej akadémie vied. Nitra 2009. Unpublished.

Žernožičková 2017 - I. Žernožičková: Late La Tène painted pottery decoration from the oppidum of Staré Hradisko. In: J. Kysela/A. Danielisová/J. Militký (eds.): Stories that Made the Iron Age. Studies in Iron Age Archaeology dedicated to Natalie Venclová. Prague 2017, 223-241.

Mgr. Marek Gere

Podunajské múzeum v Komárne

Palatínova 13

SK - 94505 Komárno

marek.gere@gmail.com 
